\title{
Transfer study expands
}

\section{Washington}

A suBCOMMITTEE of the US Recombinant DNA Advisory Committee (RAC) lifted restrictions on the number of patients for a key gene transfer trial last week, but postponed a decision on an application for the first gene therapy experiment.

At the meeting of a subcommittee of RAC, members voted unanimously to lift the cap on patient numbers, now set at ten, for the continuing gene transfer study of patients with widespread melanoma. Although, in principle, the patient-number limitation has been removed, the Institutinal Biosafety Committee (IBC) of the National Institutes of Health (NIH) has requested a temporary cap of 50 patients.

The study, sanctioned in January 1989 after a lengthy federal review process, is a joint effort between W. French Anderson of the Heart, Lung and Blood Institute and R. Michael Blaese and Steven A. Rosenberg of the National Cancer Institute (NCI). It involves readministering interleukin-2-stimulated T-lymphocytes marked with the gene for neomycin resistance to patients from whom the cells were isolated. Although the gene confers no therapeutic benefit, it allows the researchers to track the cancer-killing tumourinfiltrating lymphocytes (TIL) in the patient's body. So far, six of the ten patients have been treated, with data on the first five submitted to the New England Journal of Medicine. The TIL appear to 'home' to the tumour site, but whether this correlates with anti-tumour activity has yet to be determined.

Now that researchers have established that the gene transfer protocol is safe, they hope to introduce genes of therapeutic value, such as tumour necrosis factor and interferon. Rosenberg will be submitting the next phase of the TIL protocol for review within two months, but because the subcommittee and the RAC meet infrequently the protocol will be subject to delays of six months or more.

No decision was reached by the subcommittee in its review of the first human gene therapy protocol, which is proposed by Blaese. It is designed to treat ADA (adenosine deaminase) deficiency - a rare inherited immune disorder affecting fewer than 20 people worldwide. Lack of a functional ADA gene accounts for about UK RESEARCH FUNDING

\section{Polytechnics still persecuted?}

\section{London}

BRITISH universities and polytechnics have diverged in their responses to a Department of Education and Science (DES) consultative paper which suggests changes in the method of funding for British scientific research.

The paper proposes reform of the 'dual support' system, whereby the universities receive nearly $£ 620$ million a year from the Universities Funding Council (UFC) to cover research costs, in addition to research council grants. The government argues that the distinction between universities' and research councils' funding responsibilities has become increasingly blurred, and propose a transfer of $£ 70$ million a year to the research councils from 1991 92 (see Nature 343, 199; 18 January 1990). Research council grants will then include a component for overheads.

The dual support system has never embraced the polytechnics, which have no large research component in their block grants from the Polytechnics and Colleges Funding Council (PCFC).Understandably, the Committee of Directors of Polytechnics (CDP)'s view is that the proposals are merely "a very cautious tinkering" with an unjust system. One delegate at a CDP conference, called to discuss the proposals, described the present situation as a "dramatic intellectual apartheid".

The CDP is annoyed that the consul- tative paper proposes a shift of some of the PCFC's minimal research support to the research councils, while leaving most of the UFC's research money untouched. It suggests a larger transfer of UFC funds (so that research council grants would cover all the costs associated with research projects, including academic salaries), to enable the polytechnics to compete equally.

This view was pressed strongly by Professor Terence Burlin, rector of the Polytechnic of Central London, at the CDP conference. He asserted that, with the exception of medical, dental and veterinary schools, universities have no additional costs that merit the continuance of the dual support system.

For the universities, the Committee of Vice-Chancellors and Principals (CVCP) says that any transfer of UFC money may threaten their research. The CVCP argues that difficulties with the present system lie in underfunding, not in the balance of responsibility between universities and research councils.

But Sir Graham Hills, principal and vice-chancellor of the University of Strathclyde, believes the government's planned expansion of higher education is possible only if teaching and research are costed separately, and one approach would be to dismantle the dual support system.

Peter Aldhous

\section{Indians say give us Nature! \\ New Delhi}

EIGHTY-three per cent of Indian scientists polled recently want the government to rescind a 50-year-old policy that prevents foreign publishers of scientific journals from bringing out Indian editions. And more than 90 per cent of would like to see Indian editions of Nature, Science and Naturwissenschaften, while two-thirds want local editions of New Scientist, Scientific American and La Recherche as well.

The opinion poll was conducted by Current Science, a journal of the Indian science academy, at the request of the Department of Science and Technology (DST). DST is reviewing the existing ban on foreign publications, introduced in the early 1950 s out of fears that allowing Indian editions of foreign journals would stifle the growth of local science journals (see Nature 341, 557; 1989).

K.S. Jayaraman

25 per cent of children who have severe combined immunodeficiency syndrome (SCID). Children with SCID due to ADA deficiency can be cured in 30 per cent of cases where a suitable sibling-matched bone-marrow donor can be found.

Absence of a functional ADA gene results in the build-up of a toxic chemical that destroys the immune system. Blaese hopes to correct the ADA deficiency by inserting a normal ADA gene into T cells recovered from the patient using the same transfer methods used in the TIL protocol.

But the review coincidentally came in the same week as the US Food and Drug Administration (FDA) approved the use of polyethylene glycol-conjugated bovine ADA (PEG-ADA) as another treatment for ADA deficiency. With two potential therapies for $\mathrm{ADA}$ deficiency, recruitment of patients could become more difficult, says Abbey Myers of the National Organisation for Rare Disorders, a subcommittee member.

Blaese said that "there is no question that patients are getting better on PEGADA, but the real issue is can we do better for them?". In the protocol guidelines, it is envisaged that most of the patients will be receiving PEG-ADA as well as gene therapy. PEG-ADA will be withdrawn only when the ADA genemodified $T$ cells have been shown to be effective by themselves.

The proposal must wait for further scrutiny by the subcommittee on 1 June, then go to the full RAC in October for final approval.

Henry I. Miller of the FDA expressed concern that the long delays in the review process caused by "gratuitous overregulation" will serve as a "disincentive to' carry out research and development".

Dlane Gershon 